\title{
AUSCHWITZ EN BERGEN-BELSEN: LA FIGURA DEL TESTIGO Y LOS DISCURSOS CINEMATOGRÁFICOS SOBRE LOS CAMPOS EN LA INMEDIATA POSGUERRA, 1945-1948
}

\author{
PEDRO PAYÁ LÓPEZ \\ Universidad de Alicante \\ pedro.paya@ua.es
}

(Recepción: 13/11/2014; Revisión: 13/01/2015; Aceptación: 16/06/2015; Publicación: 26/11/2015)

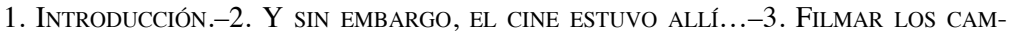
POS: LA MIRADA DEL TESTIGO.-4. El DISCURSO POR EL MONTAJE: EL VALOR DE LA PRUEBA DOCUMENTAL Y LA IMAGEN DEL INFIERNO.-5. EL GESTO DEL CINE.- 6. EL TESTIMONIO DESDE LA FICCIÓN: OSTATNI ETAP.-7. CONCLUSIÓN: LA MIRADA HACIA LOS LÍMITES Y LOS LÍMITES DE LA REPRESENTACÓN.- 8. BIBLIOGRAFÍA
\end{abstract}

\section{RESUMEN}

Este artículo estudia el papel jugado por el testigo en las primeras representaciones cinematográficas de los campos de concentración y de exterminio. Se centra en los testimonios recogidos por dos figuras que son, a su vez, dos puntos de vista ante el acontecimiento: el de quien lo ha vivido (superstes), como la directora Wanda Jakubowska, y el de quien ha asistido como tercero (testis), los camarógrafos que filmaron la liberación de los campos. En el umbral de la visión del horror, desde la ficción y el documental, ambas formas de testimonio nacieron como miradas que se interrogaron por la representación de una evidencia que se mostraba como lo real impensable. Luego, tras el montaje, la absorción por el espectador fue inseparable de la representación y el imaginario, de una visión del mundo que iba más allá de la mirada que filma. Y esa visión del mundo era la del infierno de Bergen-Belsen y de Auschwitz, campos modelos -en occidente y en el este- a partir de los cuales comenzó a construirse la primera memoria sobre los crímenes del nazismo, condicionada por la interpretación jurídica y política del acontecimiento. Solo la ficción fue capaz de mostrar la especificidad reservada al pueblo judío: la diferencia entre campos de concentración y de exterminio.

Palabras clave: Auschwitz; memoria; cinematografía; testigo; George Stevens; Wanda Jakubowska. 


\title{
AUSCHWITZ IN BERGEN-BELSEN: THE FIGURE OF THE WITNESS AND CINEMATOGRAPHIC DISCOURSES ON CONCENTRATION CAMPS IN THE IMMEDIATE POST-WAR PERIOD, 1945-1948
}

\begin{abstract}
This paper studies the role played by the witness in the first cinematic representations of concentration and extermination camps. It focuses on the testimonies gathered by two different figures that become, in turn, two points of view of the happenings: the vision of the one who lived through it (superstes), as is the case with Wanda Jakubowska Director, and the vision of the one who was present as a third party (testis), the cameramen who filmed the liberation of the camps. On the very threshold of this vision of horror, from fiction to the documentary, both forms of testimony came into being as perspectives that doubt the representation of the evidence shown as an inconceivable reality. Then, after the montage, the internalization by the spectator becomes inseparable from the representation and the imagery of a vision of the world that went beyond the figure that films. And that view of the world was the hell of Auschwitz and Bergen-Belsen, model camps -in the West and in the East- from which the first memories began to be constructed based on the earliest reports of the crimes of Nazism, conditioned by the legal and political interpretations of the happenings. Only fiction was able to show the specificity reserved to the Jewish people: the difference between the concentration and the extermination camps.
\end{abstract}

Key words: Auschwitz; memory; cinematography; witness; George Stevens; Wanda Jakubowska.

\author{
$* \quad * \quad *$ \\ Recordaré muy bien lo que he visto, vivido y aprendido, \\ lo que la naturaleza humana me ha revelado. \\ HANNA LÉVY-HASS \\ Diario de Bergen-Belsen \\ Todo es una ilusión, \\ todo lo que alguna vez te pareció real es ilusorio. \\ Lo único seguro, indudable y real es el humo. \\ SEWERYNA SzMAGLEWSKA \\ Una mujer en Birkenau
}




\section{El campo de concentración sólo es imaginable como literatura, no como realidad.}

IMRE KERTÉSZ

Diario de la galera

\section{INTRODUCCIÓN*}

En El castillo de Barba Azul George Steiner afirmaba que no es el pasado lo que nos rige como colectividades políticas, sino las imágenes del mismo (1). De ahí que autores preocupados por el alcance moral de la memoria como Tzvetan Todorov hayan apostado por unir el recuerdo del siglo xx a la experiencia extrema de sufrimiento y terror vivida en los campos de concentración (2). Era allí, como ya escribiera Hannah Arendt, donde el poder no encontraba límites y se cumplía la creencia fundamental del totalitarismo: todo es posible (3).

No es de extrañar, por lo tanto, que el nombre de Auschwitz (campo símbolo de la Shoah) se haya convertido hoy en la piedra angular de la memoria colectiva de occidente, auténtica metáfora del siglo XX como siglo de guerras, totalitarismos, genocidios y crímenes contra la humanidad (4). Y establecer el nombre de un campo como lugar central de esa memoria necesariamente implica tener en cuenta la voz de quienes sobrevivieron a los mismos, de tal forma

* Con mi agradecimiento a los evaluadores externos, cuyos comentarios y sugerencias han ayudado a mejorar este texto.

(1) STEINER (2006): 17.

(2) TODOROV (1991).

(3) ARENDT (2006): 589.

(4) No fue siempre así. Memoria incómoda en otro tiempo, cuando la deportación política ocupaba la atención y las narraciones sobre la resistencia nacional antifascista proliferaban a modo de mito positivo a partir del cual reconstruir una Europa humillada que no quiso mirar al colaboracionismo, necesitó de dos generaciones para constituirse en ese «gigantesco punto negativo», tal cual lo ha denominado Imre Kertész, del que partiera una nueva conciencia europea. LAGROU (1997). Si hoy Auschwitz ocupa ese lugar central es desde una constatada ambivalencia y dinámica evolución en las formas institucionales de memoria, en relación a los distintos significados que se confiere al acontecimiento según la situación -geográfica y generacional-que se haya tenido frente al mismo. Young (1993). Así, debemos diferenciar entre los significados atribuidos a la memoria de la Shoah en Europa occidental, cuyo reconocimiento supone un auténtico «billete de entrada en la Unión Europea»-JUDT (2006): 1145-, de la memoria ligada a la identidad judía y a la legitimación misma del Estado de Israel, o la construida en EE.UU., donde el holocausto ha sido acogido como un auténtico «acontecimiento refugiado»-DONESON (2002): 4-, y como tal ha sido moldeado y dotado de un particular significado en coherencia con los valores predominantes en la sociedad estadounidense, hasta el extremo de poder hablar de una «americanización del holocausto», término acuñado por Michael Berenbaum. Especial mención merece la forma en la que se mira la Shoah en algunos países de Europa oriental, como Polonia, Hungría y los países bálticos, donde la conflictiva memoria con su otro pasado totalitario la hacen profundamente ambigua. DŁUGOBORSKI (1997). 
que la experiencia vivida ha pasado a ser considerada fuente de conocimiento histórico, destacando una figura clave: la del testigo (5).

Parece que, con el cambio de siglo, lo que ha terminado abriéndose camino definitivamente es una valoración de la experiencia de sufrimiento, recogiendo lo que ya en su Dialéctica negativa escribiera Theodor W. Adorno; a saber: que la necesidad de prestar voz al sufrimiento es condición de toda verdad (6). Una verdad que necesariamente ha de pasar por la voz de las víctimas, por lo que Reyes Mate ha denominado autoridad del testigo (7).

Es objeto de este trabajo preguntarse qué ha aportado el cine, testigo privilegiado del siglo XX, al conocimiento y representación de ese lugar central de la memoria colectiva de occidente que hoy se concentra en el nombre de Auschwitz. Más concretamente, qué papel ha jugado en sus primeras representaciones cinematográficas la figura del testigo. O lo que es lo mismo, y como se preguntara Imre Kertész respecto a la literatura, ¿ha sido el cine capaz de crear una imagen relevante de la Shoah? Y si así ha sido, ¿ha servido para integrarla en nuestra cultura ética; es decir, para establecer un punto de partida que nos permita interrogarnos sobre la verdadera naturaleza del ser humano? ¿Se ha quedado, en cambio, sólo en lo superficial, formando parte cada vez con mayor presencia de una industria cultural preocupada por el consumo de masas?

Para el nobel húngaro superviviente de Auschwitz y otros campos, si se mantiene el recuerdo vivo de lo sucedido no será por los discursos oficiales, sino por las vidas de aquellos supervivientes que dieron testimonio de la verdadera condición humana (8). Haciendo nuestra esta afirmación, partimos de la hipótesis de que cuando el cine ha sido capaz de aportar algo al conocimiento de los campos lo ha hecho recogiendo la voz del testigo (9). En nuestro caso prestaremos atención a la figura del testigo entendido desde dos de sus acepciones que son, a su vez, dos puntos de vista ante el acontecimiento: el de quien lo ha vivido, lo ha hecho suyo como parte de su experiencia y está en condiciones de contarlo a los demás (superstes), y -tal y como lo concibe el Derecho- el de

(5) WIEVIORKA (2009).

(6) ADORNO (2005): 28.

(7) MAte (2003). Huelga decir que la indispensable aportación del testigo para reconstruir experiencias como el sistema concentracionario y la solución final no debe suplantar sino sumarse y complementar otras perspectivas necesarias, como la visión de los verdugos y el funcionamiento de su sistema y que tan magistralmente ha sabido conciliar Saul Friedländer. De especial interés son también las aportaciones realizadas por Christopher Browning y Daniel Goldhagen, cuyos estudios, aunque desde perspectivas teóricas y metodológicas muy diferentes, desplazaron la atención de los campos de exterminio a las ejecuciones masivas realizadas en el este por los Einsatzgruppen.

(8) «El Holocausto como cultura», en KERTÉsz (1999): 73-85.

(9) Hay que seguir insistiendo en la importancia que la película Shoah (1985), de Claude Lanzmann, ha tenido en la toma de conciencia del genocidio judío y en la plena integración del testimonio entre las fuentes del conocimiento histórico. TRAVERSO (2007): 60. 
quien ha asistido como tercero y puede dar testimonio de lo que ha visto (testis) (10). En el primer caso abordaremos el estudio de la obra de una superviviente de Auschwitz, Wanda Jakubowska, que vivió el horror de Birkenau y dirigió en 1947 su primera película sobre aquella experiencia, Ostatni etap (11). Respecto al segundo, testis fueron los camarógrafos y operadores cinematográficos de los ejércitos aliados y soviético que (vi)vieron las consecuencias del terror (el horror) cuando descubrieron o liberaron los campos de concentración y de exterminio, con especial mención a la labor realizada por George Stevens y su equipo del Special Coverage Unit (SPECOU), incorporados al Signal Corps del ejército de los EE.UU., y a los camarógrafos del British Army's Film and Photographic Unit (AFPU), dirigidos por Sidney Bernstein. Estas filmaciones fueron recopiladas en dos películas de montaje de parecido corte, con funciones cercanas, aunque con diferencias significativas: Nazi Concentration Camps, que se exhibió como prueba en el juicio principal de Núremberg contra los jerarcas nazis y la que terminaría titulándose Memory of the Camps, proyecto de película inconclusa finalmente relegada al olvido y no estrenada hasta 1984 con dicho título (12). A estas películas hay que sumar dos grabaciones de naturaleza muy distinta: el que sería el primer testimonio cinematográfico de Samuel

\section{(10) Agamben (2005): 15.}

(11) Estrenada en 1948, Wanda Jakubowska rodaría otras dos películas sobre la experiencia en los campos: Koniec naszego swiata (1964) y Zaproszenie (1985). MAZIERSKA (2006): 154-155. Además y aunque no fueran realizadas por testigos que sufrieron la experiencia directa de los campos, sí debemos mencionar, por su clara proximidad, las que pasan por ser las dos primeras películas que representan la Shoah desde una perspectiva inequívocamente judía. Daleká cesta (1949) del checo Alfréd Radok y la germano-estadounidense Lang ist der Weg (1949) de los refugiados Herbert B. Fredersdorf y Marek Goldstein. La primera fue rodada en el invierno de 1948 en el lugar mismo de Theresienstadt, donde el padre y el abuelo de Radok habían perdido la vida, y contó con la colaboración en el guion de Erik Kolar, exdeportado de Theresienstad. Con una puesta en escena expresionista que subraya fuertemente la subjetividad, Radok representa la realidad del campo-gueto como una pesadilla absurda, grotesca y caótica, con la que trata de imaginar el destino final de su pueblo entre las ahora calles desiertas de Terezín. Estamos ante una visión personalísima que no deja de ser una constatación in situ del peso del trauma en el superviviente. CIESLAR (2005): 220. La segunda se basó en el guion casi autobiográfico de Israel Becker, quien consiguió burlar el destino para el que había sido condenado junto a su familia al evadirse del transporte que lo conducía a Auschwitz. La película narra el internamiento de la familia protagonista en el gueto de Varsovia, su posterior transporte a Auschwitz y la vida en el interior del campo para desplazados (DP) de Landsberg en la inmediata posguerra, y de nuevo destacan las escenas de estilo expresionista, como la de los rostros de las víctimas de la selección fundiéndose con el humo de las chimeneas de los crematorios. La mayor parte fue rodada, sin embargo, en el mismo Landsberg, el mayor de los DP que existían en la zona estadounidense de ocupación de Alemania, y contó con el propio Becker para el papel principal, además de completar el reparto con los propios refugiados del campo.

(12) Memory of the Camps es el título asignado en 1984 por el Imperial War Museum, que custodiaba desde 1952 el material filmado y montado en Londres de forma inconclusa en 1946. Aunque varios autores datan su estreno en 1985 (emitida por la TV inglesa con el título de $A$ Painful Reminder) una primera versión fue proyectada en el Festival de Berlín el 27 de febrero de 1984. Gladstone (2014): 71-72. 
Fuller, rodado con una pequeña cámara de $16 \mathrm{~mm}$ como soldado de la primera división de infantería del ejército de los Estados Unidos -la Big Red One-, cuando liberó Falkenau, comando de Flossenbürg (13). Particular mención merece la película rodada también en $16 \mathrm{~mm}$ en el campo de Westerbork, lugar de tránsito para los judíos holandeses que fueron destinados en su mayoría a los campos de exterminio de Sobibor y Auschwitz-Birkenau, aunque unos pocos pudieron ir a Bergen-Belsen y Theresienstadt. La película fue filmada por $\mathrm{Ru}-$ dolf Breslauer -prisionero judío del campo finalmente deportado y asesinado en Auschwitz-, por encargo del comandante SS de Westerbork, Albert Gemmeker. Se trata de la única película rodada en los campos antes de su liberación. Concretamente, filmó la partida de un tren hacia Auschwitz con 691 deportados el 19 de mayo de 1944, entre ellos la niña gitana de diez años de edad Anna Maria Settela Steinbach, cuya asustada mirada a cámara pone rostro al exterminio y que Alain Resnais inmortalizara en su Nuit et Brouillard (14).

\section{Y SIN EMBARGO, EL CINE ESTUVO ALLÍ...}

Jean-Luc Godard sugería que el cine, herramienta y lenguaje privilegiado para mostrar el siglo xx, había fracasado ante el mismo precisamente por no haber estado presente para filmar y mostrar los campos de la muerte. Fue allí donde la llama del cine, en palabras del cineasta suizo, se extinguiría definitivamente (15). Sin embargo, desde su liberación, cineastas de distintas generaciones se han preguntado qué mostrar sobre los campos y cómo hacerlo. Y lo han hecho desde postulados éticos y estéticos muy distintos, siempre en relación a una responsabilidad de la mirada que va desde categorías externas al cine como lo indecible hasta otras como banalización, para la que, gracias a la fuerza que en nuestras sociedades tiene el estatus de la imagen, juega hoy un papel privilegiado. Así, podemos afirmar, a grandes rasgos, que el papel jugado por las imágenes cinematográficas en la construcción de la memoria de los campos ha pasado de servir como prueba en la denuncia inmediata del horror a la banalización a la que asistimos en la actualidad, consecuencia de su entrada en la industria cultural tras el éxito en 1993 de la aclamada y premiada película del director y productor Steven Spielberg, Schindler's List y

(13) Sin embargo, los camarógrafos estarían en una posición intermedia entre ambas acepciones de testigo, ya que si bien habían visto como terceros las consecuencias del terror y como tales filmaron lo que vieron sabiendo que constituiría un testimonio prueba del crimen cometido, también sufrieron la experiencia de situarse directamente ante el horror, viéndose afectados por el mismo. Pero no llegarían a ser superstes, en tanto su significado fuerte hace referencia «al que ha sobrevivido». BENVENISTE (1983): 402-405.

(14) Película nunca acabada, se conservan noventa minutos de tomas mudas que Harun Farocki rescató y montó para realizar Respite, Silent movie, Harun Farocki Filmproduktion, 2007.

(15) RANCIÈRE (2005): 197-215. 
que suponía el punto culminante de un proceso de americanización del holocausto iniciado quince años antes con el lanzamiento y masiva difusión de la teleserie Holocaust (16). Como provocadoramente afirmara Jean-Luc Godard, desde entonces el «nunca más» se ha convertido en el «siempre igual» (17). Lo que no deja de sorprender, como ha advertido Didi-Huberman, es el hecho de que en este recorrido el carácter testimonial de las primeras filmaciones en los campos haya ido perdiendo significación hasta el extremo de verse cuestionadas como forma de memoria de la Shoah. Para el autor francés, las imágenes rodadas en los campos nunca habrían tenido una legibilidad apropiada, de tal forma que a su equívoca interpretación originaria como metonimia de los crímenes nazis le habría sucedido -en el otro extremo- la puesta en cuestión de su capacidad de mostrar (18).

(16) Holocaust (1978) constituyó un giro decisivo en la manera de representar y hablar sobre el genocidio judío no solo en los EE.UU., donde la vieron 100 millones de telespectadores, también en la República Federal de Alemania, donde lo hicieron otros 20 millones y suscitó un importante debate público que posibilitó que la sociedad alemana se enfrentara de forma inusual hasta ese momento a los crímenes del nazismo. NovicK (2007): 229-234; WiEviORKA (2009): 129-140; JUDT (2006): 1156-1157. En este sentido, más allá de la trivialización que acompañó a la popularización del acontecimiento, es clara su influencia en lo que James E. Young ha denominado «las consecuencias de la memoria», en relación al impacto que en la cultura popular tiene ciertas formas convencionales de representación -Young (1993): 11-15-, que fueron indudables. No solo como paso decisivo en la presencia pública de la Shoah, también por su influencia en la creación y proyección de estereotipos como los de las mismas víctimas, asociadas a la pequeña burguesía judía asimilada de Europa occidental. Pero cuando el acontecimiento se atenúa y diluye, ¿puede haber una auténtica memoria del mismo? ¿Se tradujo esta imagen relevante en conocimiento de la Shoah? Como ha escrito Peter Novick «no respondemos a los acontecimientos sino a sus representaciones, solo una minoría de los judíos europeos asesinados por Hitler se parecía a los estadounidenses de clase media», al contrario de los judíos polacos, que hablaban yiddish y eran padres de familias numerosas. NOVICK (2002): 229; WIEVIORKA (2009): 133. Judith Doneson, por su parte, y aunque reconoce las alteraciones y distorsiones que sufre el acontecimiento real, encuentra también resultados positivos en la popularización de la memoria de la Shoah a través de producciones como Holocaust o Schindler's List al haber favorecido su penetración en la conciencia estadounidense, «ya que la alternativa ofrecida por la ausencia de representaciones populares puede ser-escribe- desinterés y desconocimiento». Doneson (2002): 226. Pero si la popularización del acontecimiento real tenía un precio lógico en su representación -ha escrito Imre Kertész- con el tiempo ha dado lugar a una estilización que ha cobrado «dimensiones insoportables». KERTÉSZ (1999): 88.

(17) GODARD (2007): 135. Al hilo de lo comentado en la nota anterior, desde Schindler's List se han multiplicado las producciones sobre el mal llamado Holocausto hasta convertirlo en todo un subgénero cinematográfico. Qué duda cabe que forman parte de una más amplia industria cultural que contempla al mundo editorial y turístico, y cuyo paradigma lo encontramos en el casi parque temático en el que el gobierno polaco ha convertido el museo de Auschwitz I. El propio Imre Kertész tras su regreso al antiguo campo en el año 2000 recomendaba no visitarlo: «La vergüenza de esa excursión me perseguirá mucho tiempo... advierto a quien piense en ir que no lo haga. Está montado para el turismo», en «El nobel ante el espejo», El País, 27 de septiembre de 2007.

(18) Didi-HubERMAn (2006): 1021. En esta línea se ha expresado también Arturo Lozano, reivindicando la necesidad de volver a poner en su contexto original -de gestación y recepción- 
Y sin embargo, el cine estuvo allí. Desde 1942 el Office of Strategic Services del ejército de los EE.UU., dirigido por William J. Donovan, había integrado una unidad de fotografía y cinematografía (Field Photographic Branch, FPB) cuya dirección fue encomendada a John Ford. Una de sus funciones era conseguir pruebas -escritas y fotográficas- de supuestos «crímenes de guerra», tal y como reflejaba uno de los epígrafes de los partes informativos quincenales (19); sin embargo, recogiendo una tradición anterior, los objetivos últimos del material recopilado por la unidad eran la propaganda: convencer al público americano e instruir a los soldados acerca de las razones de la participación de EE.UU. en la guerra y la naturaleza del enemigo al que se enfrentaban y cuyo punto culminante fue Why We Fight, serie de siete documentales producida y supervisada por Frank Capra entre 1942 y 1945 con la que respondía al encargo realizado por el jefe del Estado Mayor del ejército de los EE.UU., George C. Marshall (20).

Por su parte, el general Dwight D. Eisenhower, comandante en jefe de las Fuerzas Expedicionarias Aliadas, pidió a George Stevens que formara una unidad especial para cubrir la entrada en Francia y liberación definitiva de Europa, dando lugar a SPECOU, puesta directamente bajo el control del Cuartel General (SHAEF). Pero nada de ello anticipaba el horror con el que se encontrarían en abril tras recibir y cumplir una orden que cambiaba la naturaleza de su función: reunir pruebas fotográficas e irrefutables que demostraran al mundo y al futuro Tribunal Militar Internacional de Justicia los crímenes cometidos por el régimen nazi. De nuevo, la orden procedía del general Eisenhower, esta vez tras visitar junto a George S. Patton y Omar N. Bradley el recientemente descubierto campo de Ohrdruf, comando de Buchenwald (21).

A su vez, el Estado Mayor del Ejército Británico impulsó un proyecto conjunto entre Gran Bretaña y los EE.UU. que sería confiado a Sidney Bernstein, jefe de la Sección Cinematográfica de la Psychological Warfare Division (PWD), adjunto también al SHAEF. La idea original de Sidney Bernstein -que data de febrero de 1945- era producir una película sobre los campos de concentración utilizando el material rodado hasta entonces. Pero nada de lo encontrado y rodado hasta ese momento en el avance de las fuerzas aliadas hacía presagiar las imágenes que los equipos de Bernstein y Stevens se encontrarían tras la liberación respectivamente de Bergen-Belsen y Dachau: el horror iba a

unas imágenes que por su posterior evolución han devenido en «simbólicas y planas», perdiendo su más concreta significación y la radicalidad de su mostración en 1945. LOZANO AGUILAR (2007): 62 .

(19) Delage (2001): 65.

(20) GiRONA (2007): 41-43.

(21) La visita fue realizada el 12 de abril de 1945, ocho días después del descubrimiento fortuito del campo. Eisenhower ordenaría a las unidades que estuvieran cerca que acudieran a verlo, además de cablear a Washington pidiendo el envío de delegaciones oficiales y de periodistas para que dieran noticia de ello a su retorno. WIEVIORKA (1992): 78. 
cobrar forma, desbordando completamente la naturaleza inicial dada a ambos proyectos.

\section{FILMAR LOS CAMPOS: LA MIRADA DEL TESTIGO}

Lo que filmaron los operadores que entraron en los campos era un acontecimiento en su sentido fuerte: aquello que hiere marcando un antes y un después de manera que nada puede volver a ser lo mismo. Un acontecimiento, por tanto, que les impediría volver a mirar como lo habían hecho hasta entonces (22). En el caso particular de Samuel Fuller tuvo algo de fundador, cuando su experiencia como soldado sumido en la violencia de guerra lo convirtió inesperadamente en testigo mediante la imagen de su dimensión concentracionaria y, por extensión, en cineasta (23). Tras treinta y cinco años, terminaría llevando a la representación cinematográfica su experiencia en Falkenau en forma de ficción autobiográfica en la película The Big Red One (1980). Se trata de la conocida secuencia en la que el soldado Griff descubre los hornos crematorios y procede a abrirlos uno a uno. Encontramos la vivencia que inspiró esa secuencia en sus memorias:

«Una última visión del horror nos esperaba en el crematorio... todo estaba silencioso. Las puertas de acero de los hornos se alineaban ante nosotros. Me fijé en los hornos y miré en el interior del primero. Cuando vi los restos de los cuerpos calcinados, no pude controlar mi asco. Vomité. Quería salir de allí a cualquier precio, pero no pude evitar mirar en el segundo horno, después en el tercero, completamente hipnotizado por lo imposible. ¡Dios mío! ¡Habían asado a personas en esos malditos hornos! La prueba irrefutable la tenía ante mis ojos» (24).

Por su parte, lo que George Stevens vio en Dachau cambiaría su vida y obra cinematográfica para siempre y, como en el caso de Fuller, el crematorio perturbó de forma particular su capacidad de entendimiento. Tras filmar el humo que todavía serpenteaba desde algunas chimeneas del campo, bajó la lente de la cámara hacia el montículo de varios metros que tenía delante de sus ojos, pero lo que vio lo horrorizó: «Nos acercamos a la leña, y la leña era gente» (25).

Aunque estas breves pero contundentes palabras son muestra del estupor que debió haber sufrido ante lo que se abría a sus ojos, difícilmente hoy seremos capaces de entender lo que supuso esta primera visión si no la contextualizamos. En primer lugar lo inesperado. Cuando todo parecía acabar llegaron las

(22) Como ha precisado Joan-Carles Mélich la palabra acontecimiento, Ereignis en alemán, tiene un significado contrario a conocimiento, pues en el mismo siempre tiene lugar una especie de cambio, de novedad que rompe la historia y el fluir del tiempo. «El auténtico acontecimiento hiere, es demoledor... instaura la significación, una significación que no solamente no brota del yo sino que desubjetiviza. Pura exterioridad.» MÉLICH (1998): 81.

(23) Delage y Guigueno (2004): 46-58.

(24) FULLER (2010): 75.

(25) HARRIS (2014): 370-371. 
visiones de crueldad extrema en el trato a los prisioneros, los miles de cadáveres desperdigados o apilados, desnutridos y en estado de descomposición, la omnipresente pestilencia, los vivos vestidos con andrajosos pijamas de rayas, famélicos y demacrados, que apenas se diferenciaban de los muertos. Samuel Fuller, que había vivido en primera línea los horrores del combate durante años, lo denominó lo imposible:

«Ves gente viva con muertos, y no puedes apreciar la diferencia. Personas que se arrastran. Personas que han muerto. ¿Pero están muertos? (...) Ves un hombre moverse. Aún no está muerto, pero muere (...) Al final de toda esta guerra, está lo imposible» (26).

En el caso de George Stevens, su faceta de cineasta le condujo en un principio a emprender labores de propaganda para el Estado Mayor en el frente del norte de África, pero la experiencia de guerra iría alejándole de su asignación original para ir dejando paso al testimonio. Primero en el desembarco de Normandía y después cuando se vio inmerso junto a su equipo en la batalla de Las Ardenas teniendo que enfrentarse cara a cara con el miedo y el verdadero horror de la guerra. Pero nada de ello hacía presagiar ni había preparado a los miembros de SPECOU para afrontar lo que encontrarían al final de la misma. Al contrario, tras filmar el encuentro con las tropas soviéticas en el Elba dos semanas después, lo que certificaba la ocupación de Alemania por ambos frentes, esperaban encontrarse pronto en Berlín para filmar la derrota definitiva del Reich alemán. Pero las órdenes que recibieron les llevarían en otra dirección, $300 \mathrm{~km}$ hacia el sur, donde estaba a punto de liberarse el campo de concentración de Dachau. En el camino, las imágenes de cientos de prisioneros alemanes custodiados por los aliados y aviones derribados en los que todavía podían apreciarse las esvásticas daban forma concreta a la derrota. El tan ansiado final de la guerra parecía llegar, pero fue entonces cuando un 29 de abril también se paró el tiempo para los miembros de SPECOU y, como recordara Stevens, «todo el mal sería expuesto en un día en un campo de concentración» (27).

Con la apertura de los campos los operadores se enfrentaron a una realidad para la que no habían sido preparados. De todas las instrucciones recibidas ninguna decía cómo enfrentarse a tal escala de sufrimiento y muerte sin precedentes y aunque tanto los miembros de SPECOU como los del AFPU se habían curtido en la batalla con la visión de cadáveres de los soldados muertos en combate o incluso de civiles bajo los bombardeos aéreos, todo ello no dejaba de articularse en un universo de sentido que no era ajeno al de la muerte en tiempo de guerra, una muerte esperada, que formaba parte de lo posible. Nada que ver con las pilas de cadáveres desnudos, famélicos y desarticulados que encontraron en los campos. Como recordó el sargento Oakes, uno de los fotógrafos que entró en Bergen-Belsen, «no lo entendíamos. Habíamos visto cadáveres, había-

(26) Narboni y Simsolo (1986): 117. Citado por Didi-Huberman (2006): 1038.

(27) HARRIS (2014): 373. 
mos visto nuestras propias bajas, pero esos cuerpos sin derramamiento de sangre...» (28).

En segundo lugar, en la experiencia de un campo que se abre se impone la imperiosa necesidad de ayudar a personas que acaban de ser liberadas de un sufrimiento extremo y presentan tal absoluta debilidad que su salvación puede depender de horas. Las respuestas se multiplicaron entre los camarógrafos. Algunos de los hombres de SPECOU dejaron voluntariamente sus cámaras, incapaces de filmar entre tanto sufrimiento sin hacer lo poco que pudieran para intentar paliarlo. Como el mismo George Stevens manifestara, «cuando encuentras cosas que están en su peor momento, y (es) más necesario filmarlas, no puedes hacerlo como deberías. No puedes acercarte a un hombre que piensa(s) en salvarlo, y... clavar una cámara en su cara» (29). Otros, en BergenBelsen, ante los miles de cadáveres en putrefacción apilados en montículos de varios metros, tuvieron que desviar la mirada o simplemente se derrumbaron llorando con la mirada perdida en el vacío (30), aunque algunos encontraron en la lente una especie de parapeto ante el horror y pudieron seguir filmando (31).

Porque, y en tercer lugar, sintieron el deber de cubrir con sus escasos medios lo máximo que pudieran, conscientes de la importancia que su testimonio podría tener como prueba del crimen y como memoria para la posteridad, lo que les ayudó a superar la tensión emocional y psicológica a la que se enfrentaban, además del terrible olor que se había apoderado del aire y que hacía el trabajo «extremadamente difícil». William Lawrie, uno de los camarógrafos que filmó en Bergen-Belsen, lo expresó con enorme sencillez: «esa atmósfera tenía que ser grabada de alguna manera» (32). Y Stevens, el cineasta de mayor prestigio que había sirviendo en el frente, se sintió en la obligación y deber de no dejar de usar su cámara, a la vez que trataba de proteger al resto de su equipo de las escenas más crudas:

(28) HAGGiTH (2005): 35.

(29) HARRIS (2014): 370-371.

(30) ZELIGER (1997): 69.

(31) HaGgith (2005): 39.

(32) Ibídem, p. 38. Conscientes de los límites de la imagen para transmitir el verdadero horror que estaban presenciando, los camarógrafos del AFPU que rodaron en Bergen-Belsen intentaron reflejar algo de dicha atmósfera filmando al conductor de la Bulldozer que arrastraba a cientos de cadáveres hacia la fosa común haciendo muecas y escupiendo, o, como en el caso de los planos sobre los alemanes que fueron obligados a asistir al entierro de las víctimas, con pañuelos sobre su nariz, imagen que también sería registrada por George Stevens en Dachau y por Samuel Fuller en Falkenau. Fue la forma que encontraron para trasladar a la imagen algo que, por definición, presenta límites infranqueables. Como declarara Jorge Semprún: «¿Sabe usted qué es lo más importante de haber pasado por un campo? ¿Sabe usted que eso, que es lo más importante y lo más terrible, es lo único que no se puede explicar? El olor a carne quemada... Yo tengo dentro de mi cabeza, vivo, el olor más importante de un campo de concentración. Y no puedo explicarlo.» El País, 19 de agosto de 2000. 
«Puedes mandar tres o cuatro tipos con algunas armas para hacer algo, pero no puedes enviar a nadie al maldito vagón de carga. Tuve que hacerlo. Y trepé sobre esta cosa y la gente (que estaba viva) pocos días antes, estaban apilados... Uno apenas podía saber... ello sencillamente no estaba vinculado con personas, la manera en la que estaban todos apilados uno encima del otro... Así que estoy aquí, y estoy viendo estas personas... En el vagón. Dios mío, cómo hace uno...» (33).

Si la experiencia de Falkenau fue determinante en la vida de Samuel Fuller, convirtiéndolo en cineasta, Dachau hizo a Stevens cambiar incluso su noción acerca de la naturaleza humana, pues tuvo la agudeza de saber apreciar que estaba ante el lado más oscuro de la misma. Fue allí donde, según sus propias palabras, aprendió sobre la vida, y no poder evitar cierta repugnancia cuando algunos deportados llenos de llagas y piojos se le acercaban dirigiéndose a él en lenguas que no conocía lo salpicó de esa responsabilidad que Karl Jaspers llamó metafísica, Hannah Arendt calificó de universal ineludible y atormentó a Primo Levi al sentir que pertenecía a la misma especie que había hecho posible Auschwitz (34):

«Odiaba a aquellos bastardos (prisioneros nazis)... Y sin embargo, cuando un pobre hombre hambriento y ciego porque su vista está fallando me agarra y empieza a rogar, yo siento al nazi en cualquier ser humano... Me siento un nazi porque yo lo aborrezco y quiero que me quite las manos. Y la razón por la que lo aborrezco es porque me veo a mí mismo siendo capaz de mostrar arrogancia y brutalidad para mantenerlo alejado... Es algo violento de descubrir eso dentro de ti mismo, todo lo que desprecias al máximo» (35).

Como Fuller, Stevens se llevó de vuelta a Estados Unidos las bobinas que había rodado con su cámara de $16 \mathrm{~mm}$ a color, almacenándolas sin que fueran mostradas públicamente hasta después de su muerte. Demasiado traumáticas para volverlas a ver, etiquetó las latas con títulos como «Atrocidad» o, más significativamente, «Testigo en Dachau». (36)

(33) Según cuenta Mark Harris, George Stevens se reservó el trabajo más doloroso para sí mismo, preguntándose durante toda su vida si había filmado lo suficiente y sido capaz de trasladar a sus conocimientos «la crueldad y diligencia» requeridas para filmar a las víctimas. HARRIS (2014): 371.

(34) JASPERS (1998); ARENDT (2005): 153-166; LEVI (1998): 194.

(35) Citado por HARRIS (2014): 373.

(36) George Stevens trató de proyectar en una única ocasión las películas almacenadas. Lo hizo en 1959, cuando preparaba el rodaje de El diario de Anna Frank y quiso mostrarlas a algunos de los miembros de su equipo. Pero después del primer minuto apagó el proyector sin que le fuera posible visionarlas. HARRIS (2014): 444. 


\section{EL DISCURSO POR EL MONTAJE: EL VALOR DE LA PRUEBA DOCUMENTAL Y LA IMAGEN DEL INFIERNO}

La mirada del testigo que abre el campo es la mirada inocente de aquel que ha de enfrentarse estupefacto al horror y saber sopórtalo sin dejar de filmar (37). Un testigo consciente de la necesidad de la mirada y del uso de la misma cuando se ve obligado a romper todos los tabúes heredados en la mostración de cadáveres y de seres vivos andrajosos e indefensos. Para decirlo con Jean-Luc Nancy, una mirada llevada a la intensidad de una evidencia que es, a su vez, «la evidencia y la certeza de una mirada (regard) cinematográfica como miramiento (égard) con el mundo y con su verdad» (38).

Estas miradas, que suponían testimonios fílmicos de primera mano rodados con cámaras de $16 \mathrm{~mm}$, a color por un profesional y en blanco y negro por un aficionado, no fueron hechas públicas hasta los años ochenta. Sin embargo, el material rodado por los camarógrafos británicos y estadounidenses pronto se convertiría en toda una iconografía del horror, ligando la idea misma de campo de concentración a su representación y alimentando la mayoría de las películas documentales que con posterioridad se han realizado sobre los campos (39).

Pero en su momento tuvieron una primera legibilidad que fue deudora de su contexto, y además de ser exhibidas de forma compartimentada en los noticiarios de la época, dieron lugar a dos películas documentales con montajes muy distintos y con funciones asimismo diversas aunque muy cercanas en torno a la idea de responsabilidad: Nazi Concentration Camps, que el fiscal de los

(37) Como lo ha expresado Serge Daney en referencia a George Stevens y Samuel Fuller, «la inocencia es la gracia terrible otorgada al primero que llega y debe ejecutar, simplemente, los gestos del cine» DANEY (1992).

(38) NANCY (2008): 65. Explica Nancy: «La mirada es un miramiento y, por tanto, un respeto. La palabra respeto tiene que ver con regard (respicere): es una mirada dirigida hacia..., guiada por una atención, por una observancia o por una consideración» (p. 90). A su vez, evidencia, en su sentido fuerte, tendría un significado cercano al de acontecimiento, entendida no como «aquello que cae bajo el sentido, sino lo que golpea y cuyo azote abre una ocasión para el sentido. Es una verdad, no en tanto que correspondencia con un criterio dado, sino en tanto que sobrecogimiento» (p. 94). Como ha evidenciado Toby Haggith, los camarógrafos que rodaron en Bergen-Belsen no abandonaron las pautas habituales para la representación de los muertos y el cuerpo humano por insensibilidad hacia los deportados, sino con el fin de transmitir la brutalidad del sistema de campos y de compilar un informe de pruebas irrefutables para acusar a un régimen que despreciaban. HAGGiTH (2005): 45. Cosa bien distinta es la utilización que hoy día se sigue haciendo de estas imágenes para producir documentales sobre los criminales del nazismo utilizando formas que, como lo ha expresado Harun Farocki, llegan a ser indignantes. FAROCKI (2009): 16.

(39) SÁncheZ-Biosca (2004): 110-124. No solo. Las imágenes de los cadáveres y los supervivientes esqueléticos se convierten en ocasiones en el principio y final del conocimiento popular de la Shoah, desplazando y reduciendo peligrosamente todo un largo proceso de deshumanización, expropiación, reclusión, deportación, selección, esclavitud y exterminio final -que se inicia con las primeras leyes raciales de abril de 1933 y concluye con el último campo liberado- a un «enorme espectáculo de víctimas de atrocidades». Young (1988): 163. 
EE.UU. Robert H. Jackson exhibió como prueba acusatoria durante el primer juicio de Núremberg contra los principales jerarcas del Partido y Estado Nazi, y el proyecto impulsado por Sidney Bernstein y abortado finalmente por el Foreign Office, cuando la realidad de la guerra fría impidió que fuera estrenada hasta los años ochenta con el título de Memory of the Camps, desnaturalizando así la función primera para la que había sido concebida: enfrentar a la sociedad alemana, mediante su visionado en las salas cinematográficas, con la responsabilidad colectiva de unos crímenes que se habían cometido en su nombre y -lo que era peor- cerca de sus casas y no habían querido ver (40).

Aunque Nazi Concentration Camps debía mostrar las pruebas que confirmaran la política de agresión de Alemania, estas se basaban en la mostración de un horror hasta entonces inimaginable, por lo que sus referentes de significado estarían más allá de cualquier crimen cometido en guerras anteriores, para situarse en un imaginario transhistórico del mal: la imaginería del infierno a través del arte y la literatura (41). Y esta parece haber sido precisamente la opción elegida por George Stevens y Ray Kellogg, realizador y montador de la pelícu-

(40) La nueva estrategia del Foreign Office pasaba por exculpar a la sociedad alemana de unos crímenes que tendrían como únicos responsables a las cabezas políticas y militares más visibles. LINDEPERG (2000): 235; GLADSTONE (2014): 75-77. Desgajados del proyecto común inicial y para cumplir con dicho objetivo, los estadounidenses realizaron su propia película bajo la supervisión y montaje de Billy Wilder y Hans Burger. De 22 minutos de duración, fue estrenada en enero de 1946 con el título Die Todesmühlen (Death Mills). Los informes recabados por el US Information Control División concluyeron que aunque los espectadores alemanes tomaban conciencia de los crímenes cometidos, no daban muestras de sentir ningún tipo de responsabilidad por ellos. GLANDSTONE (2005): 61. Y ello pese a la contundencia de prólogo, guion y un vigoroso montaje que comienza en abril de 1945 con cientos de alemanes marchando con cruces en los hombros para dar sepultura a las más de 1.000 víctimas encontradas en Gardelegen, y concluye en una serie de imágenes significativamente paralelas de cientos de miles de alemanes vitoreando a Hitler en 1934 extraídas de Triumph des Willens, que se funden encadenadamente con las de los habitantes de Weimar forzados a visitar Buchenwald y de nuevo la secuencia inicial de los lugareños portando las cruces. La voz en off es contundente: «Estos alemanes, que afirmaban desconocerlo todo, también eran responsables. Habían puesto alegremente su destino en manos de unos criminales lunáticos. Ahora todos juntos afirmaban no saber nada de lo que estaba pasando... Ninguna pesadilla veló los sueños de aquellos que vivían junto a los campos... Son los mismos alemanes que una vez vitorearon a Hitler. Recordad, aunque ahora porten una pesada cruz, ellos son la cruz de millones de crucificados en las fábricas de muerte de los nazis.»

(41) Como ha escrito George Steiner, «El campo de concentración encarna, a menudo hasta en minuciosos detalles, las imágenes y crónicas del infierno representadas en el arte y el pensamiento europeos desde el siglo XII al XVIII. Y son estas representaciones las que dieron a los descompuestos horrores de Bergen-Belsen una especie de 'lógica esperada'». STEINER (2006): 76. En efecto, ante la insuficiencia del lenguaje y del pensamiento para dar cuenta de la novedad que representaba la experiencia en los campos, la imagen del infierno fue invocada por los supervivientes, por quienes cubrieron la liberación de los campos (Vasili Grossman tituló «El infierno de Treblinka» su artículo sobre el descubrimiento del antiguo emplazamiento del campo en 1944), por quienes trataron de pensar la barbarie (Hannah Arendt escribió sobre «La imagen del infierno» en 1946), e incluso por los verdugos, como queda demostrado en el diario del médico de Auschwitz Johann Paul Kremer. WIEvIORKA (1992): 180. 
la, al haber dotado a la misma de una estructura narrativa claramente dantesca, basada en el descenso a los infiernos a través de doce círculos, que son los doce campos de concentración que aparecen en la misma (42).

Así, los campos mostrados -entre los que no se diferencia su función o grado, pues recogen campos de concentración, pequeños comandos y clínicas de experimentación y asesinato como Hadamar- tampoco siguen un orden que responda a la cronología de su liberación, que es alterada en favor de la mostración -y definición- de un horror que va en aumento hasta llegar a los últimos círculos del infierno, que se corresponden con las imágenes de Mauthausen, Buchenwald, Dachau y Bergen-Belsen, momento en el que el horror alcanza límites de atrocidad insoportables, constituyéndose como un hito en la historia de la imagen (43). Era la forma más adecuada no solo de «establecer hechos increíbles por medio de pruebas creíbles», como declarara el fiscal Robert $\mathrm{H}$. Jackson, sino también de enclavarlos en un universo de significado que ha recorrido la tradición occidental.

Sin embargo, el discurso que acompañaba a las imágenes iba al mismo tiempo a desnaturalizarlas, al tratar de adaptarlas a lo que el equipo de Robert H. Jackson consideraba la causa determinante de todos los crímenes nazis: los cometidos contra la paz. Así, Nazi Concentrations Camps se constituye como una película que trata de mostrar los crímenes de un Estado agresivo contra sus enemigos políticos, ocultando completamente el genocidio judío, palabra que únicamente aparece una vez en la película (44).

(42) Stevens y Kellogg utilizaron 1.800 de los 24.000 metros rodados por los equipos de SPECOU, AFPU y FPB. No debemos despreciar la dureza y dificultades del trabajo en la sala de montaje. Peter Tanner, uno de los montadores de Memory of the Camps, recordaba en 1984 que los proyeccionistas de la sala de montaje estaban tan horrorizados que miraban la película y si se desenfocaba tenía enormes dificultades para atraer su atención para que la arreglaran. GLADSTONE (2014): 79.

(43) Precisamente la estructura dada a Memory of the Camps es la inversa. Tras dedicar los primeros 32 minutos a las imágenes rodadas por los operadores del ejército británico en BergenBelsen -sin duda, las más crudas y atroces- la película disminuye su horror tanto por las características propias de las imágenes rodadas en otros campos como por su redundancia hasta la saturación, ya que no se trata más que de una acumulación que se precipita en los 24 minutos restantes dedicados a otros nueve campos. La gran paradoja es que Auschwitz aparece en último lugar, tanto desde el punto de vista del metraje, como de la intensidad decreciente del horror representado, lo que se ve agudizado, además, por una voz en off que oculta la verdadera naturaleza del campo como lugar de exterminio de los judíos europeos: «Presos de toda la Europa ocupada eran transportados aquí para su ejecución.»

(44) Aunque la película parecía constituir un auténtico cuerpo del delito para el cuarto cargo de la acusación: conjura, crímenes contra la paz, crímenes de guerra y crímenes contra la humanidad, la supeditación de este último al segundo influyó notablemente en el discurso global de la película, cuya banda sonora alteraría considerablemente el verdadero significado de unas imágenes que, en realidad y como el propio fiscal Jackson había adelantado cuando las presentó como prueba en su auto de acusación, hablaban por sí mismas. DougLas (2000): 252. 
La primera secuencia nos pone ya en situación. Sobre un mapa de Europa en el que se escriben los nombres de los campos de concentración y exterminio con su estructura radial de comandos, una voz en off comenta: «Este informe cubre un grupo representativo de esos campos e ilustra sus condiciones generales.» Sin embargo, esta referencia no solo no contemplaba la diferencia ontológica entre campos de concentración y de exterminio, tampoco tenía en cuenta que las «condiciones generales» que registraron los camarógrafos a su llegada a campos como Dachau y Bergen-Belsen estaban alteradas por la hambruna provocada por el abandono que de la administración de los campos hizo el Reich alemán en su desmoronamiento y por la llegada masiva de decenas de miles de deportados, en su mayoría judíos, que fueron evacuados en las marchas de la muerte desde los campos situados en el este ante el avance del ejército soviético, y que eran mucho peor tratados que aquellos deportados políticos sometidos al régimen de los campos de concentración de Alemania, de por sí durísimo (45).

En su huida, los nazis habían intentado destruir las pruebas de la solución final a tres niveles: la documentación generada, las instalaciones del crimen y los cuerpos de las víctimas, todavía vivos, que se llevaron consigo. Si la documentación fue destruida en su mayoría y las cámaras de gas y crematorios hechos saltar por los aires, no tuvieron tanto éxito para deshacerse, por falta de tiempo, de los cuerpos - con vida y sin vida- de las últimas víctimas de la solución final. Es en este sentido coyuntural en el que podemos afirmar, tal y como se indica en el título de este trabajo, que los libertadores encontraron Auschwitz en Bergen-Belsen (46).

(45) Hannah Arendt ya observó en su momento que las imágenes mostradas resultaban engañosas en tanto no reflejaban el estado de los campos en su funcionamiento cotidiano, sino en sus últimas fases como resultado del desmoronamiento del Reich en los últimos meses de la guerra. ARENDT (2006): 599.

(46) Evidentemente el caos de Bergen-Belsen estaba en el extremo opuesto a la metódica forma de exterminio llevada a cabo en Auschwitz-Birkenau, tan contrario como la muerte por hambre, sed, malos tratos, falta de condiciones higiénicas y sanitarias, enfermedades y epidemias agudizadas como consecuencia de la superpoblación lo es a la aniquilación de aquellos que eran conducidos directamente a las cámaras de gas tras su llegada a los campos de exterminio, sin que tuvieran, por lo tanto, ningún tipo de experiencia concentracionaria. Cabe insistir, una vez más, en que a este respecto lo específico del genocidio judío fue la desaparición completa de los cuerpos, millones reducidos a cenizas, y no las pilas de miles de cadáveres. Sin embargo, debemos tener en cuenta que fue en enero de 1945, coincidiendo con el aluvión de los deportados en las marchas de la muerte y cuando el campo había pasado a estar bajo la autoridad del antiguo comandante de Birkenau, Josef Kramer, cuando el empeoramiento de las condiciones de vida cobró un ritmo vertiginoso. Josef Kramer pudo continuar en Bergen-Belsen, por lo tanto, la política de destrucción de los judíos europeos aunque por medios menos técnicos, de ahí que las montañas de cabellos, cenizas, zapatos, vestidos, lentes o cepillos aparecidos en Majdanek y Birkenau, cobraran en Bergen-Belsen su verdadero rostro como consecuencia de que la maquinaria diseñada para la solución final había dejado de funcionar. 
Y es esta situación la que explica que en Bergen-Belsen murieran 35.000 deportados entre enero y el 15 de abril de 1945, de los que 22.081 lo hicieron entre el 1 de marzo y el 6 de abril. A ellos hay que sumar los 13.944 fallecidos de entre los 60.000 prisioneros encontrados con vida desde el día de la liberación del campo, el 15 de abril, hasta el 20 de junio. Los trabajos forzados y los maltratos acumulados, las marchas de la muerte y el hambre, debilitaron los cuerpos al máximo, haciendo que el tifus y otras enfermedades proliferaran (47). Los deportados judíos que se encontraban en Bergen-Belsen antes de que comenzaran a llegar los evacuados desde el este supieron apreciar el diferente estado en el que estos se encontraban a su llegada. Así lo anotó Hanna Lévy-Hass en su diario, entrada del 6 de noviembre de 1944:

«Otro gran convoy ha llegado estos últimos días. Lo componen mil setecientas mujeres de distintas nacionalidades, la mayoría de origen judío. Vienen de Auschwitz... Tienen un aspecto que asusta: cubiertas de heridas repugnantes, enfermas, ajadas. No nos dejan acercarnos a hablar con ellas...»

Y un mes después, ya avanzado diciembre:

«Siguen afluyendo convoyes interminables. Filas de criaturas extrañas se mueven sin cesar entre los bloques y las alambradas; da pena verlas, con ese aspecto terrorífico, tan poco parecido al de los seres humanos.»

En marzo de 1945 la situación se había transformado completamente. El campo para judíos prominentes que debían ser intercambiados por prisioneros alemanes se había convertido ya en un auténtico mortuorio:

«Acabamos confundiendo a los vivos con los muertos. En el fondo, la diferencia es mínima: nosotros, unos esqueletos que aún siguen en movimiento y ellos, unos esqueletos inmovilizados... Los cadáveres, los auténticos, siguen aquí, con nosotros, en nuestras literas. No hay nadie que los retire. Ni sitio donde ponerlos. El barracón está lleno hasta los topes. En los patios también se amontonan los cuerpos, las pilas de cadáveres. Cada vez más altas. El crematorio no da abasto para quemarlos a todos... nadie se ocupa de nosotros... siento una terrible vergüenza por vivir todo esto. Los hombres se pudren y descomponen en medio del fango...» (48).

Días después los camarógrafos británicos rodaron las imágenes que antes habían visto testigos como Hanna Lévy-Hass. Sin embargo, su primera legibilidad vino condicionada por la lectura que del acontecimiento se hizo en Núremberg (49), lo que no solo contribuyó a difundir la idea de que el problema

(47) Por el contrario, a lo largo de 1944 únicamente habían fallecido 2.048 prisioneros en el campo de Bergen-Belsen. Todas las cifras citadas en HILBERG (2005): 1089.

(48) LÉVY-HASs (2006): 92, 104 y 128.

(49) Al contrario de la lectura dada a las imágenes que rodaron, los camarógrafos británicos supieron ver desde el primer día, y así lo dejaron anotado en sus informes, que «los presos que fueron llamados por los alemanes 'presos políticos' de todas las religiones y países, eran en su mayoría judíos cuyo único crimen se basaba en el hecho de que eran judíos.» Citado por HAGGITH (2005): 44. 
había quedado superado (50), también influyó para que las imágenes por medio de las que el mundo tomaba conciencia de los crímenes del nazismo fueran leídas a contrasentido (51). Porque el verdadero horror no estaba en la visión de miles de cadáveres, sino en la destrucción de millones, en lo único que por definición es verdaderamente irrepresentable: el olor a carne quemada (52).

\section{EL GESTO DEL CINE}

El acontecimiento quedaba así atrapado en su imagen y la imagen en la palabra, haciéndose muy difícil para el espectador separar la relación entre presencia (en imagen) y ausencia (la realidad del acontecimiento) de lo representado, impidiendo así, en última instancia, su distinción cognitiva (53). Tal abuso de la palabra ha estado presente en la historia del cine, como sugiere Jean-Luc Godard en sus Histoire(s) du cinéma, donde nos dice que aunque la mayoría de las imágenes del cine han estado supeditadas al poder de la palabra, la potencia de la historia de la que son portadoras permanece latente hasta que alguien las libere, permitiéndoles desarrollar su poder autónomo.

Es esta apuesta godardiana la que realiza Harun Farocki en su película muda Respite, montada a partir de los planos rodados entre marzo y mayo de 1944 en el «campo de tránsito para judíos» de Westerbork. La película fue encargada por el comandante del campo, Albert Konrad Gemmeker, a uno de los prisioneros, el fotógrafo judío Rudolf Breslauer y su asistente Karl Jordan, que se sirvieron de dos cámaras de $16 \mathrm{~mm}$. Según puede desprenderse de la mayoría de las tomas que se han conservado -y esta es la hipótesis de Harun Farocki-, fue realizada con objetivos propagandísticos para demostrar la eficacia del campo de trabajo y retrasar o evitar así la deportación hacia el este cuando la mayoría de los judíos holandeses ya lo habían sido y, por tanto, se acercaba el posible

(50) AGAMBEN (2005): 18.

(51) WIEVIORKA (1992): 209.

(52) Podemos, en este sentido, hacer nuestras y parafrasear las palabras de Chris Marker en su Level 5 en relación a la representación de la guerra: «Pero falta lo de siempre, el olor del humo. Sin un cine olfativo no habrá películas de los campos de verdad. Y mejor, no tendría público».

(53) Argumento utilizado por Marco Dinoi en su ensayo póstumo dedicado al salto cognitivo que ha supuesto la imagen televisada de los atentados al World Trade Center de Nueva York el 11 de septiembre de 2001. Del «parece real» con el que acogieron los primeros espectadores de cine las proyecciones de los hermanos Lumière hemos pasado al «parece una película» que sanciona definitivamente la falta de distinción entre lo real y lo imaginario. DiNOI (2008). No puedo dejar de citar la que para quien escribe es la más contundente confirmación a esta falta de distinción, cuando, precisamente el mismo año que se publicaba la obra de Dinoi, uno de los niños que sobrevivió al accidente del avión de Spanair que se estrelló cuando trataba de despegar de la T-4 del aeropuerto de Barajas, pregunto al bombero que lo rescató «dónde estaba su padre y cuándo terminaba la película». ¿Cuándo termina la película?, El País, 21 de agosto de 2008. 
cierre del mismo. Por esta razón, el mayor número de planos fueron rodados dando cuenta «documentalmente» del trabajo realizado por los internos (también en sus momentos de ocio, con lo que presentaría ciertas semejanzas con la realizada en Theresienstadt) a los que Farocki da una nueva legibilidad haciendo emerger la violencia oculta en las imágenes recurriendo a la historia y memoria pública de la Shoah (54). Así, y como lo ha expresado Sylvie Lindeperg:

«Sobre las escenas anodinas de la clínica dental él evoca las dentaduras que son arrancadas a los muertos en Birkenau; sobre las batas blancas de un laboratorio, los siniestros experimentos médicos practicados en Auschwitz, sobre los cables pelados en un taller, las montañas de cabello de mujer encontradas por los soviéticos. Sobre la imagen de trabajadores tumbados sobre la hierba, las de fosas abiertas y los cadáveres sobre el suelo filmados por los aliados cuando abrieron los campos... Farocki parte de una fuente única de planos para convocar imágenes-recuerdos» (55).

Sin embargo, el momento principal de la película emerge cuando dejamos a las imágenes hablar por sí mismas: en su primer plano un tren entra en la estación de Westerbork con pasajeros judíos procedentes de Ámsterdam, en su plano final otro parte hacia Bergen-Belsen (vagones de tercera) y Auschwitz (vagones de carga), dando su verdadero significado al «campo de trabajo» como «campo de tránsito» hacia el exterminio (56). Como afirma el propio Farocki en su película, alrededor de un centenar de trenes partieron de Westerbork llevándose consigo a unas cien mil personas, pero solo uno fue filmado. Probablemente, «las únicas imágenes que existen de los trenes hacia los campos de exterminio» (57).

Medio siglo antes, el 28 de diciembre de 1895 los hermanos Lumière proyectaban en París La llegada de un tren a la estación de Ciotat. Dos días des-

(54) Él mismo ha expresado que su objetivo al editar estas imágenes fue presentarlas de tal forma que el espectador pudiera realizar una lectura personal en la que jugaba un papel importante el conocimiento previo de la Shoah. FAROCKI (2009): 24.

(55) LINDEPERG (2009): 29.

(56) Es en este momento cuando se constata definitivamente la diferencia con el film rodado en Theresienstadt. Encargados ambos por el comandante SS responsable del campo, coinciden tanto en su naturaleza propagandística como en la identidad y destino del equipo de realización: prisioneros judíos que encontrarían la muerte en las cámaras de gas de Auschwitz poco después de la filmación. Difieren, en cambio, en sus apuestas, destinatarios y resultados. La de Theresienstadt fue concluida, editada en unos estudios de noticiarios checos y proyectada ante una comisión de la Cruz Roja Internacional y varios diplomáticos con el título Theresienstadt: Ein Dokumentarfilm aus dem Judischen Siedlungsgebiet. BECKER (2005): 96. Las imágenes de Westerbork, en cambio, permanecieron en estado bruto sin montar, lo que les ha hecho conservar mejor su poder autónomo. $\mathrm{Si}$ en algo se concreta esa apuesta diferente es en la presencia de este tren que parte hacia el este, ausente por completo en la película de Theresienstadt, al ser precisamente este aspecto del campogueto lo que se trataba de ocultar con la película.

(57) En total fueron deportados 105.000 judíos de los Países Bajos, de los que 4.900 y 3.750 lo fueron a Theresienstadt y Bergen-Belsen respectivamente. 60.000 fueron enviados a Auschwitz y 34.300 a Sobibor. De todos ellos sobrevivieron unos 5.000: 19 de Sobibor, unos 1.000 de Auschwitz y unos 4.000 de Theresienstadt y Bergen-Belsen. HILBERG (2005): 657-658. 
pués, un periodista anónimo escribió en un artículo aparecido en La poste una de las afirmaciones que con mayor contundencia han expresado la potente relación entre cinematógrafo, presencia y abolición del tiempo: «La muerte ha dejado de ser algo absoluto» (58). Y es ese aspecto fundacional del cine el que antes de que Farocki diera una nueva legibilidad a las imágenes del campo de Westerbork, Breslauer ya había realizado mediante el gesto único en toda la película de girar la cámara para filmar en primer plano la mirada asustada de Anna Maria Settela Steinbach desde el interior del vagón de carga, convirtiendo el encargo del comandante del campo en un lugar de memoria y en una prueba de la destrucción de los judíos europeos y del tan frecuentemente olvidado genocidio gitano (59). Si la metáfora que ha definido al cine por excelencia siempre ha sido la del tren de sombras, nunca un tren filmado por una cámara cinematográfica ha estado cargado de tanta sombra como el que partió de Westerbork hacia Auschwitz el 19 de mayo de 1944, un tren con 691 personas cuya luz quedó plasmada en el «realismo ontológico» de la emulsión cinematográfica. Y fue la luz de la sombra de Anna Maria Settela Steinbach la que iluminó años después el significado último de estas imágenes. Si su primer plano devino en los años ochenta en una imagen icónica que ponía rostro al exterminio anónimo de millones de personas, hoy sabemos que esa mirada era la de una niña de etnia gitana y ascendencia sinti, gaseada, probablemente, junto al resto de los 2.900 gitanos que quedaban en el campo de Birkenau, la noche del 2 de agosto de 1944 (60).

\section{EL TESTIMONIO DESDE LA FICCIÓN: OSTATNI ETAP}

Si los cadáveres de Bergen-Belsen y Dachau tenían su referente en la imagen del infierno que había recorrido el imaginario occidental, la verdadera esencia del exterminio carecía de imágenes (61). Así era el verdadero infierno en la descripción que Vasili Grossman hizo de Treblinka. Todo había sido des-

(58) VÉRAY (2003): 75.

(59) De nuevo se hace pertinente la comparación con la película rodada en Theresienstadt, en la que los rostros quedan perfectamente integrados en su discurso propagandístico, con primeros planos de prisioneros prominentes para que fueran reconocidos. Desde una absoluta diferencia, el rostro de Settela Steinbach detrás de la puerta entreabierta del vagón que la conduce de Westerbork a Auschwitz es sustraído de la muerte anónima mediante un plano único con el que la verdad de la imagen irrumpe superponiéndose a la mentira de la representación.

(60) La verdadera identidad de Settela Steinbach fue descubierta por el periodista holandés Aad Wagenaar. LINDEPERG (2009): 31.

(61) Sí disponemos de las cuatro fotografías realizadas por miembros del Sonderkommando desde el interior de una de las cámaras de gas del crematorio V de Birkenau. Forman una secuencia en la que se recoge a las víctimas desnudas en el bosque de Birkenau mientras se dirigen corriendo hacia las cámaras de gas y el momento posterior a su ejecución, cuando los cuerpos están siendo quemados en una de las fosas al aire libre. DiDi-HuBERMAN (2003). 
truido, cámaras de gas, barracones e incluso la estación y la línea de ferrocarril habían dado paso a un campo de altramuces. Cuando entraron en el mismo solo se escuchaba el sonido de las vainas al abrirse, formando «una única melodía, triste y sosegada». Pero el infierno había dejado su rastro, en forma de terrible olor, «un olor que ni el fuego ni el sol, la lluvia, la nieve o el viento pueden disipar» (62). ¿Cómo, pues, representarlo?

En opinión de Imre Kertész las imágenes de montones de cadáveres se cierran sobre sí mismas sin que nada más puedan ofrecer, agotando y desalentando la capacidad de imaginación (63). Y es precisamente con la ayuda de la imaginación estética con lo que según Kertész puede realizarse una aproximación a esa realidad «inconcebible e inextricable» que es la Shoah (64), y lograr transmitir así, mediante la creación «de un relato dominado»-como también defendía Jorge Semprún-, «la verdad del testimonio» (65).

No por casualidad, ambos testigos dieron cuenta de su diferente experiencia, como deportado político y como superviviente de la destrucción de los judíos europeos, por medio de la escritura literaria, además de reflexionar sobre el valor de la memoria y la amenaza del olvido. Porque fue allí, en los campos, donde el imperativo del recuerdo y la angustia por el olvido convivían en el pensamiento de las víctimas. Si no debían quedar testigos y el objetivo final de los verdugos era el memoricidio, sobrevivir para dar testimonio devino en la principal forma de resistencia, de ahí que la cineasta Wanda Jakubowska, que vivió como superstes la experiencia como deportada política en el campo de mujeres de Birkenau y como testis la destrucción de los judíos europeos, saliera del mismo sabiendo que haría una película sobre Auschwitz, eligiendo la ficción como forma de testimonio (66).

Rodada en el mismo Birkenau dos años después, contó con la colaboración de antiguas compañeras de cautiverio, entre ellas la comunista alemana Gerda

(62) El artículo sobre «El infierno de Treblinka» en BEEVOR (2006): 346-375, 351 y 374.

(63) Al encontrar su sentido en un imaginario transhistórico del mal como eran las imágenes del infierno creadas desde la Edad Media hasta el siglo XVIII, evitaban imaginar algo mucho peor que escondía el significado último del acontecimiento: el infierno moderno, ordenado, científico, técnico, burocratizado de una fabricación de cadáveres en serie supervisada por hombres ordinarios, no por seres diabólicos. TRAVERSO (2001): 235-239. Conviene en este sentido diferenciar entre imaginario, que haría referencia a lo irreal, e imaginación, capacidad creativa para dar cuenta de una realidad. FRYE (2007).

(64) KERTÉSZ (1999): 66.

(65) SEMPRÚN (1997): 25.

(66) «La dernière étape: un film entre témoignage et fiction», WIEVIORKA (1992): 293-312. Sin embargo, y aunque aquí nos ocupamos de la misma en cuanto tal, Ostatni etap no puede ser considerada únicamente una forma de testimonio del testigo. Es también una película deudora de su contexto político y cultural: los intentos de legitimación del poder comunista en la Polonia de posguerra. LIEBMAN (1998). Lo que no pone en cuestión la veracidad de los acontecimientos narrados en la misma, al quedar dividida en dos partes bien diferenciadas. Una primera claramente testimonial y una segunda que refleja inequívocamente el discurso propagandista propio del realismo socialista. MAZIERSKA (2005). 
Schneider, coautora del guion. Aunque centrada en el movimiento de la Resistencia dentro del campo, es sin duda la primera película que da cuenta de forma inequívoca del genocidio judío y el lugar central que la solución final tuvo en las políticas asesinas del Tercer Reich (67). De ahí que la vida cotidiana de las deportadas en el campo de mujeres, donde destacan por su veracidad los interminables recuentos, las marchas al trabajo y la violencia de las kapos, esté jalonada en todo momento por la llegada de trenes en la noche, las selecciones y, sobre todo, la presencia del humo oscureciendo el cielo sobre la terrorífica luz de las llamas en la noche, que las internas ven desde la distancia, lo que debe ser interpretado como «una honesta recreación de la perspectiva de los supervivientes» (68). No deja de ser significativo que la principal protagonista de la película -Martha Weiss- sea una deportada judía que se une al grupo de resistentes tras salvar su vida gracias a sus conocimientos de alemán, lo que la hará trabajar como intérprete. Momentos después de su llegada, tras ingresar en el campo de mujeres y ser tatuada, se enterará de que el resto del transporte, incluida su familia, ya había sido o estaba siendo gaseado en ese momento (69).

La película se sitúa en el epicentro mismo de la solución final, cuando la industria del exterminio ha alcanzado sus cotas más altas de perfección y eficacia: a la construcción de unidades combinadas que comprenden sala de desnudamiento, cámara de gas y hornos crematorios conectados mediante montacargas con las mismas (70), se suma, un año después, la construcción de la rampa de selección en el interior mismo de Birkenau: la llegada en masa de 437.402 judíos húngaros entre el 15 de mayo y el 8 de julio de 1944, de los que únicamente un diez por ciento fueron declarados aptos para el trabajo. Se trata de unos momentos en los que la capacidad de los hornos no era suficiente para «tratar» a 12.000 judíos diarios, por lo que fueron abiertas cinco fosas de cre-

(67) No deja de sorprender por ello que un especialista como Vicente Sánchez-Biosca haya afirmado que la película «encubre hasta la ocultación la masacre judía». SÁNCHEZ-BIOSCA (2009): 119.

(68) AVISAR (1988): 36. Estamos, por lo tanto, ante una doble naturaleza del testimonio: el de la Wanda Jakubowska miembro de la resistencia deportada al campo de mujeres de Birkenau (superstes) y el de quien solo tuvo acceso al conocimiento del proceso de exterminio por medio de la visión a distancia de los crematorios (testis).

(69) Annette Insdorf llamó la atención sobre cómo Martha, recién llegada a un mundo que desconoce, no estaba solo obligada a traducir del alemán al polaco, sino la aprensión en comprensión y los códigos de un infierno incomprensible para ella; de ahí que en sus primeras horas en el campo aprenda el significado de la palabra «musulmán» tras ver lo que a lo lejos parece una figura humana electrocutada en el alambre de espino, o que la chimenea que ve no pertenece a una fábrica sino a un lugar donde se queman seres humanos, cuyo humo proviene de los cuerpos incinerados de su transporte. INSDORF (1983): 130.

(70) Hay un momento de la película en el que asistimos a una conversación llevada a cabo en la casa del comandante del campo donde -sobre una maqueta de los crematorios II y III de Birkenau- se da cuenta de la solución encontrada a uno de los problemas perseguidos más concienzudamente por los responsables de la solución final: cómo asesinar más rápida y económicamente a un mayor número de personas. 
mación al aire libre junto al crematorio $\mathrm{V}$, donde incluso fueron violentamente arrojados niños vivos, tal y como dieron cuenta varios testimonios (71).

En una secuencia que me atrevería a calificar de sublime, Wanda Jakubowska se centra en el destino de un nuevo transporte. En esta ocasión al plano de la llegada del tren a Birkenau le sucede mediante un fundido el de la fila humana que forman quienes ya han sido seleccionados, en su mayoría niños y algunas de sus madres, que caminan hacia lo desconocido para ellos: el bosque del crematorio V de Birkenau. Mediante una cita muy cuidada, nos deja ver a una niña que lleva una pelota en sus manos y que se separa un momento del resto al ser llamada por uno de los SS que vigila la marcha. Cuando llega a su altura, el SS la mira y le pide cariñosamente la pelota, intercambiando una serie de sonrisas. A continuación la niña vuelve a la fila y un plano largo nos muestra la marcha silenciosa de los niños hacia su final, hasta desaparecer en un nuevo fundido que enlaza, mediante una elipsis que supone una declaración ética, una vez más con la imagen del humo, que en esta ocasión no sale de las chimeneas de los hornos sino de las fosas crematorias. Un nuevo plano corta la secuencia, el de la pelota que -sin dueña- es depositada en un almacén junto a otros juguetes que vemos mediante un travelling testimonial, momento en el que el documental irrumpe en la ficción: Wanda Jakubowska nos muestra las montañas de sábanas, maletas, vestidos, zapatos, cepillos, prótesis y otros utensilios robados a las víctimas antes de que fueran gaseadas, y que hoy forman parte de los pabellones 4 y 5 del museo de Auschwitz dedicados a las pruebas del crimen, en un montaje magistral (72).

Se hace pertinente hacer al menos dos comentarios de la secuencia que acabamos de narrar. En primer lugar, la descripción que se hace del verdugo, adelantándose a lo que Hannah Arendt definiría como banalidad del mal. Efectivamente, el SS que nos es mostrado no presenta en ningún momento signos de odio hacia las víctimas, apareciendo como un funcionario que simplemente realiza su trabajo sin preguntarse si está mal o bien, aunque consista en asesinar a miles de niños indefensos (73). Por ello y al mismo tiempo, también se muestra incapaz de sentir piedad, con lo que no dejaba de cumplir una de las características demandada a los SS. Fue el propio Rudolf Höß -antiguo comandante

(71) Wiesel (1996): 93; GRAdOWSKI (2008): 165; SzMAGLEWSKA (2010): 311, 325; VeneZia (2010): 101-102.

(72) No son mostradas, sin embargo, las imágenes de las siete toneladas de cabello cortado a las víctimas halladas en Birkenau y que hoy se encuentran en el citado museo. Peter Tanner, uno de los responsables del montaje de Memory of the Camps, recordó que Alfred Hitchcock, que trabajó durante unos meses como asesor en la película, consideró que estas imágenes, junto a las de algunas de sus pertenencias, eran incluso más desgarradoras y horrorosas que la mostración de los cuerpos de las víctimas. GLADSTONE (2014): 77.

(73) Ya en 1945 Hannah Arendt supo observar que la «organización omniabarcante» de Himmler no descansaba «en fanáticos, ni en asesinos natos, ni en sádicos; descansa por entero sobre la normalidad de los empleados y los cabezas de familia», en «Culpa organizada y responsabilidad universal», ARENDT (2005): 153-166, 162. 
del campo de Auschwitz que volvió interinamente a Birkenau en abril de 1944, precisamente para supervisar la construcción de la rampa de selección y la deportación de los judíos húngaros-, quien contó en sus memorias que el inspector de campos de concentración, Theodor Eicke, los aleccionaba mediante discursos sobre lo que consideraba indignidad del sentimiento de piedad y los ponía a prueba haciéndoles presenciar torturas y palizas brutales hasta la muerte de los prisioneros, para cerciorarse de que no emitían ningún sentimiento de piedad hacia los mismos (74).

En segundo lugar debemos referirnos a la descripción que se hace de la víctima. Por su ropa, el color rubio del pelo, el tocado del lazo, la niña en cuestión no deja de recordar a la que aparece mirando a la cámara a la derecha de una de las fotografías tomadas por los SS a los judíos húngaros en el bosque del crematorio V tras su llegada a Birkenau, poco antes de ser gaseados. Quien ha visto esta fotografía no puede dejar de sentirse interpelado por esa mirada. Wanda Jakubowska estaría así dando a conocer el final de la niña, completando la lectura de la imagen fija. Un contraplano que nos da a ver lo que la fotografía tomada por los SS no pretendía mostrar: su destrucción.

\section{CONCLUSIÓN: LA MIRADA HACIA LOS LÍMITES Y LOS LÍMITES DE LA REPRESENTACÓN}

En el umbral de la visión del horror, el testigo cinematográfico inauguró el tiempo de la mirada hacia los límites, antes de que se hubieran recorrido y explotado las numerosas estrategias de representación que han desembocado en una bulimia de la mirada, antes de que se hubiera puesto sobre la mesa el debate acerca de la irrepresentabilidad (75), cuando más que una teoría, un axioma o una sentencia moral, era una realidad devenida como impotencia: la distancia entre la experiencia del superviviente y el lenguaje, entre la conciencia de lo sucedido y la ausencia de categorías interpretativas para pensarlo (76). También fue el periodo en que la ficción era un elemento de construcción de lo real,

(74) Нӧв (2009): 76.

(75) Como ha escrito Saul Friedländer, el genocidio judío es tan accesible a la representación y la interpretación como cualquier otro suceso histórico. «Solo que en este caso tratamos con un hecho que pone a prueba nuestras tradicionales categorías de conceptualiación y represetación: un 'suceso límite'», en «Introducción», FRIEDLÄNDER (2007): 21-46, 23. En la misma línea, Jacques Rancière ha defendido que no hay límites intrínsecos a la representación, más allá de los que se derivan de las posibilidades de establecer una relación entre la mostración y la significación del acontecimiento. RANCIÈRE (2001): 101-102.

(76) Hannah Arendt expresó esta idea en varios de sus trabajos, quizás de la forma más contundente cuando escribió: «Pero el problema con la sabiduría del pasado es que se nos muere entre las manos, por así decir, tan pronto como intentamos aplicarla honestamente a las experiencias políticas centrales de nuestro tiempo», en «Comprensión y política (Las dificultades de la comprensión)», ARENDT (2005): 371-393, 374. 
aunque deudora de su contexto, y no una forma de reducir el acontecimiento al relato cultural.

Trascendiendo los intereses políticos, históricos y jurídicos que filtraron la evidencia y certeza de una mirada cinematográfica entendida como una ventana abierta al infierno y su verdad más oscura, había una necesidad indudable -un deber, podríamos decir- de mirada. Y la cuestión primera que se plantearon fue qué uso dar a la misma. George Stevens -que sintió en Dachau que estaba perdiendo parte de su propia humanidad- se preguntó durante toda su vida si había sido capaz de responder al desafío que había supuesto llevar a su profesión «la crueldad y diligencia necesarias» para filmar la muerte de masas. Samuel Fuller consiguió filmar lo que él mismo definió como «una lección de humanidad en veintiún minutos», en cumplimiento de la orden del capitán Kimble R. Richmond por la que los notables de Falkenau, que decían ignorar lo que había ocurrido a escasos metros de sus casas, debían rendir público homenaje a las víctimas dándoles una sepultura digna. Fuller filmó así, en medio del horror, un espacio y un tiempo de dignidad abierto por el capitán Richmond, a quien consideraba el verdadero autor de la película (77). Wanda Jakubowska optó por no mostrar la realidad más descarnada que había vivido en el campo y al final de su vida declaró que sabía que no se había equivocado (78). Las tres, pues, nacieron como miradas que, desde distintos niveles y estrategias, se interrogaban sobre la representación.

Porque aquellas miradas iban más allá de la representación, hacia la intensidad de una evidencia que se mostraba como lo real impensable. Luego, tras el montaje, la absorción de la visión por el espectador es inseparable de la representación y el imaginario, de una visión del mundo que va más allá de la mirada que filma. Y esa visión del mundo era la del infierno de Bergen-Belsen y de Auschwitz, campos modelos -en occidente y en el este- a partir de los cuales comenzó a construirse la primera memoria sobre los crímenes del nazismo, condicionada por la interpretación jurídica y política del acontecimiento. No es casualidad que fuera en Polonia y antes de su estalinización donde se realizaron las dos primeras películas que ponían sobre la mesa el genocidio judío (79). Fue el primer país que sufrió el terror del nazismo, el territorio donde quedaron emplazados los seis campos de exterminio y de esa nacionalidad eran el mayor número de judíos asesinados. También era la nación con mayor necesidad de expiación, pues no solo algunos de sus habitantes asistieron como espectadores indiferentes, sino que participaron en el exterminio, facilitando la detención o matando directamente a sus vecinos (80).

(77) Didi-HuBERMAN (2006): 1036-1039.

(78) WIEWIORKA (1992): 299.

(79) Además de Ostatni etap, en 1948 también fue estrenada Ulica Graniczna, del director judío polaco Aleksander Ford. Centrada en el levantamiento del gueto de Varsovia, fue asimismo rodada en el lugar de los hechos.

(80) GRoss (2001): Indudablemente la colaboración no fue privativa de la población polaca y se dio en la mayoría de los países ocupados por el Tercer Reich o afines al mismo. Es la principal 
La diferencia entre crímenes contra la humanidad y genocidio, entre deportación individual o de masas, entre campos de concentración y de exterminio, que ni siquiera películas de montaje de la calidad de Nuit et Brouillard pusieron sobre la mesa cuando ya habían transcurrido diez años desde los acontecimientos, había sido ya expuesta en la ficción por Wanda Jakubowska. De ahí que Ostatni etap se sitúe precisamente en el corazón mismo del universo concentracionario: el campo para mujeres de Auschwitz-Birkenau, y en la fecha donde la perseguida eficacia del exterminio llega a su punto culminante tras años de improvisación y perfeccionamiento: primavera de 1944, la destrucción de los judíos húngaros.

En definitiva, allí donde en Nazi Concentration Camps el papel fundamental viene jugado por las imágenes y un verbo que dibuja sus límites, en Ostatni etap lo hacen la elipsis y el silencio: la llegada de los trenes en la noche, la rampa de selección, unos pasos hacia lo desconocido... y chimeneas escupiendo un fuego vigoroso y un humo que cubre de horror la cúpula celeste. Así es como Jakubowska muestra la absoluta especificidad de la suerte reservada a los judíos en el sistema de campos diseñado por el régimen nazi. Y entre las pilas de cadáveres y el humo, a modo de contraplano, dos rostros que nos siguen interpelando: el de la niña húngara que pierde su pelota camino del crematorio V en un día de mayo o junio de 1944, y el de Anna Maria Settela Steinbach en Westerbork antes de cerrar el vagón que la conducirá a Auschwitz el 19 de mayo de 1944. El documental y la ficción: el testigo cinematográfico.

\section{BIBLIOGRAFÍA}

Adorno, TheOdor W. (2005) [1970]: Dialéctica negativa, Madrid, Akal.

Agamben, Giorgio (2005): Lo que queda de Auschwitz. El archivo y el testigo. Homo Sacer III, Valencia, Pre-Textos.

ARENDT, HANNAH (2005) [1930-1954]: Ensayos de comprensión, 1930-1954, Madrid, Caparrós Editores.

-(2006) [1948]: Los orígenes del totalitarismo, Madrid, Alianza.

Avisar, ILAN (1988): Screening the Holocaust. Cinema's Images of the Unimaginable, Indiana University Press.

BeEvor, ANTONy (2006): Un escritor en guerra. Vasili Grossman en el ejército rojo, 1941-1945, Barcelona, Crítica.

Benveniste, Émile (1983): Vocabulario de las instituciones indoeuropeas, Madrid, Taurus.

crítica que Tzvetan Todorov hizo a Claude Lanzmann, quien en su película Shoah presenta a la población polaca como si fuera en su conjunto antisemita y olvida el comportamiento de otras como la francesa. TODOROV (1991): 248-254. 
BeCKer, Lutz (2005): «Film documents of Theresienstadt», en HagGiTh, ToBy y Newman, Joanna (eds.), Holocaust and the movie image. Representations in film and television since 1933, London, Wallflower Press, pp. 93-101.

Cieslar, JiRI (2005): «Living with the long journey: Alfréd Radok's Daleká cesta», en Haggith, Toby y Newman, Joanna (eds.), Holocaust and the movie image. Representations in film and television since 1933, London, Wallflower Press, pp. 217-224.

DANEY, SERGE (1992): «Le travelling de Kapò», Trafic, n. ${ }^{\circ} 4$.

Delage, Christian (2001): «L'image comme preuve: l'expérience du procès de Núremberg», Vingtième Siècle. Revue d'histoire, n..$^{\circ}$ 72, pp. 63-78.

Delage, Christian y Guigueno, Vincent (2004): L'historien et le film, Paris, Gallimard.

Didi-Huberman, Georges (2003): Images malgré tout, París, Editions de Minuit.

-(2006): «Ouvris les camps, fermer les yeux», Annales, Histoire, Sciences Sociales, n. ${ }^{\circ}$ 5, pp. 1011-1049.

DinoI, MARCo (2008): Lo sguardo e l'evento. Il media, la memoria, il cinema, Florencia, Le Lettere.

DŁUGOBORSKI, WaCŁAW (1997): «Auschwitz e l'Olocausto nella memoria delle società dell'Europa Centrale prima e dopo il 1989», en PAGGi, LeONARDO, La memoria del nazismo nell'Europa di oggi, Firenze, La Nuova Italia, pp. 383-403.

Doneson, Judith E. (2002): The Holocaust in American Film, Syracuse University Press.

Douglas, Lawrence R. (2000): «Le film comme témoin», en LindePerG, Sylvie, Clio de 5 à 7. Les actualités filmées de la libération: archives du futur, París, CNRS Éditions, pp. 238-255.

FAROCKI, HARUN (2009): «Comment montrer les victimes?», Trafic, n. ${ }^{\text {o }}$ 70, pp. 16-24.

FRIEDLÄNDER, SAUL (comp.) (2007): En torno a los límites de la representación. El nazismo y la solución final, Bernal, Universidad Nacional de Quilmes.

Frye, Northrop (2007): La imaginación educada, Barcelona, Sirtes.

Fuller, SAmuel (2010): «El campo de concentración de Falkenau», Cahiers du Cinéma España, n. ${ }^{\circ}$ 35, pp. 74-76, junio.

GironA, RAMÓN (2007): «Estados Unidos en guerra Why We Fight de Frank Capra. La historia al servicio de la causa aliada», Archivos de la filmoteca, n. ${ }^{\circ}$ 55, pp. 40-57.

Gladstone, KAY (2005): «Separate intentions: the Allied screening of concentration camp documentaries in defeated Germany in 1945-46: Death Mills and Memory of the Camps», en Haggith, Toby y Newman, Joanna (eds.), Holocaust and the movie image. Representations in film and television since 1933, London, Wallflower Press, pp. 50-64.

- (2014): «Memory of the Camps: The Rescue of an Abandoned Film» en PoLlock, Griselda y Silverman, MAX (eds.), Concentrationari cinema: Aesthetics as Political Resistence in Alain Resnais's Night and fog (1955), Paperback, pp. 71-83.

Godard, JeAn-Luc (2007): Historia(s) del cine, Buenos Aires, Caja negra. 
Gradowski, Zalmen (2008): En el corazón del infierno. Documento escrito por un Sonderkommando de Auschwitz-1944, Barcelona, Anthropos.

Gross, JAN T. (2001): Neighbors. The Destruction of the Jewish Community in Jedwabne. Poland, Pirnceton University Press.

Haggith, ToBy (2005): «Filming the liberation of Bergen-Belsen», en HAGgith, ToBy y Newman, Joanna (eds.), Holocaust and the movie image. Representations in film and television since 1933, London, Wallflower Press, pp. 33-45.

HARris, MARK (2014): Five Came Back: A Story of Hollywood and the Second World War, Penguin Press, Canongate.

Hilberg, Raul (2005) [1961]: La destrucción de los judios europeos, Madrid, Akal.

Insdorf, Annette (1983): Indelible shadows. Film and the Holocaust, Cambridge University Press, Nueva York.

JASPERS, KARL (1998) [1946]: El problema de la culpa. Sobre la responsabilidad política de Alemania, Barcelona, Paidós.

Judt, Tony (2006): Postguerra. Una Historia de Europa desde 1945, Barcelona, Taurus.

KERTÉSZ, IMRE (1999): Un instante de silencio en el paredón. El holocausto como cultura, Barcelona, Herder.

LAgrou, PiETER (1997): «L'amnesia del genocidio nelle memorie nazionali europee (Francia, Belgio e Olanda)», en Paggi, Leonardo, La memoria del nazismo nell'Europa di oggi, Firenze, La Nuova Italia, pp. 329-355.

LEVI, Primo (1998): Entrevistas y conversaciones, Barcelona, Península.

LeVy-Hass, Hanna (2006): Diario de Bergen-Belsen, 1944-1945, Barcelona, Galaxia Gutenberg/Círculo de Lectores.

LiEBman, STUART (1998): «Les premières constellations du discours sur l'Holocauste dans le cinéma polonaise», en Baecque de, Antoine y Delage, Christian, De l'histoire au cinéma, Paris, Complexe, pp. 193-216.

LINDEPERG, SYLVIE (2000): Clio de 5 à 7 . Les actualités filmées de la libération: archives du futur, París, CNRS Éditions.

(2009): «Vies en sursis, images revenantes. Sur Respite de Harun Farocki», Trafic, n. ${ }^{\circ}$ 70, pp. 25-32.

Lozano Aguilar, Arturo (2007): «De Ohrdruf a Auschwitz. Un imaginario para el mal», Archivos de la Filmoteca, n. ${ }^{\circ}$ 55, pp. 58-79.

Mate, Reyes (2003): Memoria de Auschwitz, Madrid, Trotta.

MaZIERSKA, Ewa (2005): «Double Memory: The Holocaust in Polish Film», en HaGGith, Toby y Newman, JoAnna (eds.), Holocaust and the movie image. Representations in film and television since 1933, London, Wallflower Press, pp. 225-235.

-(2006): «Wanda Jakubowska: the communist Fighter», en MAZIERSKA, EwA y Ostrowska, ElzBIETA, Women in Polish cinema, London, Berghahn Books, pp. 149-165.

Mélich, JoAn-Carles (1998): Totalitarismo y fecundidad. La filosofía frente a Auschwitz, Barcelona, Anthropos.

NANCY, JEAN-LuC (2008): La evidencia del filme. El cine de Abbas Kiarostami, Madrid, Errata Naturae. 
Narboni, Jean y Simsolo, Noël (1986): Il était une fois... Samuel Fuller. Histoires d'Amérique racontées par Samuel Fuller à Jean Narboni et Noél Simsolo, Paris, Les Éditions des Cahiers du cinéma.

Novick, Peter (2007): Judíos, ¿vergüenza o victimismo? Madrid, Marcial Pons.

RANCIÈRE, JACQUES (2001): «S'il y a de l'irreprésentable», Le Genre Humain, n. ${ }^{\circ}$ 36, pp. 81-102.

-(2005): La fábula cinematográfica. Reflexiones sobre la ficción en el cine, Barcelona, Paidós.

SÁNCHEZ-BiosCA, VicENTE (2004): «Equivocas sombras. La obstinada actualidad de Auschwitz», Anthropos, n. ${ }^{\circ}$ 204, pp. 110-124.

(2006): Cine de historia, cine de memoria, Madrid, Cátedra, 2006.

(2009): «Sombras de guerra: las imágenes cinematográficas de la Shoah», Historia Social, n. ${ }^{\circ}$ 63, pp. 111-132.

SEMPRÚn, Jorge (1997): La escritura o la vida, Barcelona, Tusquets.

SzMAGLEWSKA, SEWERYNA (2006): Una mujer en Birkenau, Barcelona, Alba.

Steiner, George (2006) [1971]: En el castillo de Barba Azul. Aproximación a un nuevo concepto de cultura, Barcelona, Gedisa.

Todorov, TzVetan (1991): Face à l'extreme, Paris, Seuil.

Traverso, Enzo (2007): El pasado, instrucciones de uso. Historia, memoria, política, Madrid, Marcial Pons.

(2001): La historia desgarrada. Ensayo sobre Auschwitz y los intelectuales, Barcelona, Herder.

VÉRAY, LAURENT (2003): «L'Histoire peut-elle se faire avec des archives filmiques?», 1895. Mille huit cent quatre-vingt-quinze, . $^{\circ} 41, \mathrm{pp} .71-83$.

Venezia, Shlomo (2010): Sonderkommando. El testimonio de un judío obligado a trabajar en las cámaras de gas, Barcelona, RBA.

WIESEL, ElIE (1996): Todos los torrentes van a la mar, Madrid, Anaya \& Muchnik.

Wieviorka, Annette (1992): Déportation et Génocide. Entre la mémoire et l'oubli, París, PLON.

(2009) [1998]: L'ère du témoin, Paris, Hachette Littératures.

Young, JAMES E. (1988): Writing and rewriting the Holocaust. Narrative and the consequences of interpretation, Indiana University Press.

-(1993): The Texture of Memory: Holocaust Memorials and Meaning, Yale Universiry Press.

ZELIGER, BARBIE (1997): «La photo de presse et la libération des camps en 1945: images et formes de la mémoire», Vingtième Siècle, Revue d'histoire, n. ${ }^{\circ}$ 54, pp. 61-78. 
